\title{
Erratum to: An event-by-event assessment of tropical intraseasonal perturbations for general circulation models
}

Jean Philippe Duvel · Hugo Bellenger •

Gilles Bellon • Marine Remaud

Published online: 9 April 2013

(C) Springer-Verlag Berlin Heidelberg 2013

Erratum to: Clim Dyn (2013) 40:857-873

DOI 10.1007/s00382-012-1303-6

This article was originally intended to appear in the special issue 'IPSL and CNRM global climate and Earth System Models'. Owing to an unfortunate oversight, it was published in vol. 40, nos. 3-4.

The online version of the original article can be found under doi:10.1007/s00382-012-1303-6.

J. P. Duvel $(\bowtie) \cdot$ M. Remaud

Laboratoire de Météorologie Dynamique, Institut Pierre

Simon Laplace, Ecole Normale Supérieure, Paris, France

e-mail: jpduvel@1md.ens.fr

H. Bellenger

Laboratoire d'Océanographie et du Climat, Expérimentation

et Approches Numériques, Institut Pierre Simon Laplace,

Université Pierre et Marie Curie, Paris, France

G. Bellon

Centre National de Recherches Météorologiques,

CNRS/Météo France, Toulouse, France 